\title{
Belphégor
}

\section{The middlebrow Spanish Civil War film: a site of mediation between culture and history.}

Laura J. Lee Kemp

\section{(2) OpenEdition}

\section{Journals}

\section{Electronic version}

URL: http://journals.openedition.org/belphegor/979

DOI: 10.4000/belphegor.979

ISSN: 1499-7185

Publisher

LPCM

Electronic reference

Laura J. Lee Kemp, "The middlebrow Spanish Civil War film: a site of mediation between culture and history. », Belphégor [Online], 15-2 | 2017, Online since 02 November 2017, connection on 19 April 2019. URL : http://journals.openedition.org/belphegor/979; DOI : 10.4000/belphegor.979

This text was automatically generated on 19 April 2019

\section{(c) () $\odot$}

Belphégor est mis à disposition selon les termes de la Licence Creative Commons Attribution - Pas d'Utilisation Commerciale - Pas de Modification 4.0 International. 


\title{
The middlebrow Spanish Civil War film: a site of mediation between culture and history.
}

\author{
Laura J. Lee Kemp
}

1 Film and fascism are strange yet frequent bedfellows in European cinema, and the events surrounding the Spanish Civil War and the early years of Francoism are no exception. Since the late 1990s, films about those on the losing side have constituted an impressive quantity of middlebrow productions that continues to grow and expand. Sabine Hake has described the German equivalent of this phenomenon as 'the fascist imaginary in postfascist cinema', a movement that articulates the feelings of nonfascists towards the historical, social and cultural effects of fascism. ${ }^{1}$ Hake's term can be bilaterally applied to the case of Spain, describing a set of films that share a thematic focus on the victims of Francoism and their individual struggles against the oppressive fascist state. These films could be described as a sub-genre of historical, or heritage, cinema insomuch as they share a temporal location (from 1936 to the late 1940s), a geographical location (mainland Spain), a limited range of archetypal characters, familial story lines and a number of recurrent motifs (such as the war-time role of women). Under Auteurist directors such as Victor Erice and Carlos Saura during the 1970s, this genre was politically rebellious, steadfastly highbrow, at times inaccessible, and polemical without fail. The best known examples include Erice's cryptic tale of sullied childhood innocence in The Spirit of the Beehive (El espiritú de la colmena, 1973), and Saura's evocative Raise Ravens (Cría cuervos, 1976); a touching meditation on the tropes of memory and trauma.

2 In the forty years since Franco's death, the genre has not abated. Rather, it has prospered; at the time of writing over thirty films which are set in the period of 1936 to 1950 have been produced in Spain since the turn of the twenty-first century, along with countless television productions. Yet the style of these films has become much more accessible, and since the late 1990s the genre can be located firmly under the term 'middlebrow'. Indeed they have been described by Sally Faulkner as constituting a 'middle-brow thread which crosses into the Millennium. ${ }^{2}$ The Civil War middlebrow genre is exemplified by works of 
popular narrative screen media with high production values. These films attempt to portray the serious subject matter of the fratricidal conflict in an accessible manner, whilst containing brief references to high culture. There is a consistent emphasis on the family environment in a way that brings ideological conflict firmly into the personal, familial sphere. Attempts to integrate different spectatorial positions are also a critical element of this middlebrow thread, designed to prioritise an emotive response from the viewer. By analysing two recent productions of recognised popularity; The Sleeping Voice ( La voz dormida, Benito Zambrano, 2012) and Blind Sunflowers (Los girasoles ciegos, José Luis Cuerda, 2008), I will demonstrate that the shared characteristics of emotive affect, realist aesthetics and the merging of oppositional binaries enables this sub-genre of the middlebrow to develop and explore, often in challenging and novel ways, the social trauma of victims of the war and the early years of Francoism. By addressing these lingering cultural anxieties, the middlebrow continues to validate its enduring significance within Spain as a popular medium of social discourse that mediates between culture and history.

3 Yet this very prolific genre is often snubbed by films critics and widely dismissed in the Spanish press. The prevalence of critical Marxist perspectives amongst the majority of Spanish film scholars and key cultural gatekeepers has resulted in an overriding preference for politically dissident cinema since the end of the dictatorship, which is stringently not a feature of the middlebrow. Faulkner has argued that the top-down construction of a middlebrow Spanish film culture was a strategy for integrating the new democratic order, or the 'transition to democracy', which was implemented after the death of Franco in $1975 .{ }^{3}$ The fusion of high and low culture into formally accessible films reflects the prescriptive policies of the progressive Socialist Government which was seeking to promote democratic values and a new 'Europeanised' self-image. ${ }^{4}$ The PSOE government appointed female director Pilar Miró as the new Director General of Cinema in 1982. Various protectionist policies were passed in 1983, including the provision of subsidies for films which were considered of 'special quality' and additional financial aid for new projects. The number of foreign films distributed within Spain was increased, with the expectation that the quantity of Spanish productions would fall, but that those produced would be of a higher quality. ${ }^{5}$ The definition of such 'quality', as upheld by Miró and those in charge of the allocation of grants and prizes, was centred upon literary adaptations, often with a historical setting, a 'quality' realist aesthetic and formal accessibility. The intention was for these films to have the widest commercial appeal possible, in order to offset the financial risks taken on by the government through the numerous subsidies. This has been termed Cine Polivalente, or 'multipurpose cinema' and it was both liberal and didactic. It was also arguably middlebrow.

4 The growing corpus of contemporary films about the victims of Francoism and the Civil War are similarly middlebrow and follow other generic conventions specific to the Cine Polivalente; they are often based on literary adaptations, have historical settings and use a realist aesthetic that is formally accessible. There is usually an emphasis on family relationships and quotidian settings, combined with contrasting references to 'higher' culture such as poetry and art. This fusion of 'high' and 'low' is one key characteristic of the middlebrow, which was criticised by sociologist Pierre Bourdieu as presenting an artistic confusion masked as cultural legitimacy. Bourdieu described the middlebrow as 'a series of genres half-way between legitimate culture and mass production', ${ }^{6}$ but more recently it has been recognised for its ability to assimilate inaccessible works of art into 
readily-available and formally intelligible renderings. Another identifiable characteristic of middlebrow cinema, more pertinent to this article, is what Faulkner has called 'its especial ability to "work through" or "handle" change'. ' Faulkner has explored the generic continuities that can be found across divergent forms of the middlebrow within Spanish cinema, focussing on how it has helped to articulate and process the changes brought about by class mobility in Spain from the 1970s onwards. In a similar vein, I would like to focus on middlebrow cinema's ability to mobilise discourses of cultural and post-conflict trauma. Civil War heritage films and television productions form a subgenre of the Spanish middlebrow which is exceptionally, yet controversially, well-suited to the exploration of socially and culturally traumatic themes.

Popular narrative cinema that deals with traumatic episodes of conflict, notably incidences of genocide, has been criticised for attempting to exploit historical events that should, in essence, resist narrative arcs of completion or redemption. The most paradigmatic of these examples is the Holocaust, an event of incomprehensible horror that resists representation and understanding, thereby condemning normative representational practices to inevitable failure..$^{8}$ In her reading of a collection of contemporary middlebrow Holocaust films, Lassner has listed a number of generic conventions that could be considered representational failings from the perspective of experimental or art-house cinema, such as the use of pathetic fallacy to convey emotional registers. ${ }^{9}$ However, these middlebrow techniques have the advantage of making otherwise inaccessible stories of horror and suffering readable, through emotional registers and narrative forms which are familiar and comprehensible to a wider audience. This, argues Lassner, should be 'an educational imperative' for any cinematic production concerned with the Holocaust. After all, films that deal in the 'repellent and unadventurous trajectory of despair, death, and disillusionment usually play to limited art house audiences'. ${ }^{10}$ I do not propose to conflate the two very distinct genres of Holocaust and Spanish Civil War cinema, but Lassner's comments elucidate an ethical attitude towards the middlebrow which can be productively applied across disparate genres and subject matters. The middlebrow enables mainstream access to discourses around trauma and conflict that would otherwise remain shrouded in secrecy and darkness; an all-too-familiar occurrence in regards to the Spanish Civil War. ${ }^{11}$

\section{Perpetrator trauma and guilt in Blind Sunflowers}

Civil War films usually pivot around the trope of enmity, or the distinction between the opposing factions of 'us' (supporters of the fallen Spanish Republic who are associated with the democratic ideals of inclusion, liberty, equality and justice) and 'them' (supporters of the fascist state who are depicted as violent, bigoted, racist, oppressive, and blindly obedient). As Hake has noted in relation to Nazi cinema, this enmity combines the public and private spheres around a core antagonism between the two sets of characters. Those that represent the fascist state are usually poorly articulated, onedimensional villains, placed in opposition to characters that embody the core values of democracy and are fully articulated within familial or social contexts. ${ }^{12}$ Jose Luis Cuerda's adaptation of Blind Sunflowers (Los Girasoles Ciegos, 2009) offers a more nuanced and complex interpretation of this dynamic through the character of Salvador, played by Raul Arévalo. I would like to propose that with its emphasis on the primacy of emotion, the 
middlebrow enables narratives of empathy to develop within contexts that usually promote division and incomprehension.

7 Franco's supporters have traditionally been rendered on screen in an incontestably negative light, with examples such as the ex-combatants in Saura's The Hunt (La caza, 1966) who are consumed by their mutual jealousies and display overpowering predispositions towards violence, or Sergi López's classic Nazi-esque villain, Capitan Vidal, in Pan's Labyrinth (El laberinto de fauno, 2006). Yet a more sympathetic or complex portrayal of a Francoist, or vencedor, raises questions of shared psychological, political and moral responsibilities. So the representation of perpetrators in cinema about the Spanish Civil War is weighted with ethical responsibility not just for the filmmakers, but for the wider society to which these individuals belonged. The complex figure of Salvador constitutes a site where a perpetrator's guilt and residual trauma is interwoven with Catholic shame to create a man who is presented as both victim and perpetrator, challenging the accepted binaries of good versus evil and left versus right that dominate a lot of Civil War narratives. Based on the novel of the same name by Alberto Méndez, Blind Sunflowers narrates the fatal intertwining of the lives of the Mazo family, supporters of the former Spanish Republic, and the young deacon Salvador, during the early 1940s in Ourense. The disorientated deacon returns to the seminary of Ourense after fighting for the Francoist forces, where the Rector delays his entry into priesthood for a year and instead orders him to teach in the seminary school. This is where Salvador meets Lorenzo Mazo, son of Elena, whom he believes to be a widow. However, Elena's husband Ricardo is still alive and hiding behind a wardrobe in their apartment. Salvador's interest in both mother and son increases as the scholastic year progresses, until his intrusion into their lives has dramatic consequences for the Mazos. Salvador means 'saviour' in Spanish, an ironic reference considering he is the agent of the family's demise. The film's narrative arc follows the familiar middlebrow structure of intimate character development in a familial setting, the presentation of a moral and physical threat culminating in a dramatic conclusion. The realist style of the production is unchallenging but effective at portraying an 'authentic' heritage feel through modest props and costumes, reframing once again the primacy of historical reconstruction which is so characteristic of the middlebrow. The narrative is structured around the contrast between private and public, an opposition which is conveyed through the cinematographic relationship with light. The Mazo's apartment has, metaphorically and visually, been rigorously sheltered from the light for years in order to protect Ricardo who is hiding inside. All scenes inside their home are rendered on screen in dark greens, greys and blues, with a mise-en-scène that emphasizes shadows, mirrors, secrets and dusty books. This darkness represents safety, comfort and protection, whereas the brash Spanish sunlight that burns on the streets, in the school yard and finally into their home, signifies the danger and oppression of the Francoist state. This inverted opposition between light and dark, which is so prominent within the film, 'stress[es] the disruption that the war and the defeat have constituted for the vanquished', ${ }^{13}$ a disruption that has forced a liberal and highly educated man to live in the shadows. Salvador, however, is depicted in both burning sunlight, in the schoolyard and on the street, and in near-darkness, inside the seminary and his boarding house. The contrast between his public, Catholic persona and his sexually tormented private life is also reflected in this disruption between light and dark.

8 Salvador's character similarly straddles the gulf that lies between the oppositions of victim and perpetrator. When in earnest conversation with his Padre near the beginning 
of film, Salvador complains of the guilt he feels about his comportment during the war, simultaneously expressing remorse whilst denying his own responsibility for these acts. 'Why did you send me to war Father?' he asks, before recounting the terrible sights he encountered in the impersonal third person, deflecting his own complicity in the violence; 'It's just that one sees things, Father, one has to live through things. ${ }^{14}$ Yet although Salvador's initial positioning within the film as a perpetrator of violence is only exacerbated by his desire to lay all responsibility at the feet of the church, he is in fact victimised by the Catholic Church.

9 Salvador has been indoctrinated not only by religious dogma, but also by fascist rhetoric. The combination of fascism and Catholicism particular to Francoist Spain, Nacionalcatolicismo or National Catholicism, was an ideology that upheld the absolute hegemony of the Church within all spheres of private and public life. Salvador's position as a Deacon has also forced him into a state of reluctant celibacy. Through his delusional admiration for Elena, Salvador blurs the distinctions between religious devotion and sexual fetishism, conflating the iconic figure of Eve with his own private image of Elena. This desire soon turns into an obsession which, combined with Salvador's aggressive piety, leads him to psychologically transform Elena into a Catholic martyr. Yet within the walls of her family's apartment, Elena's character is a direct and overt subversion of the public Francoist concept of womanhood. In a poignant reversal of traditional patriarchal structures, she is the one responsible for protecting her son and husband from the perils of the outside world. She is resilient, socially adept, educated, and an atheist; she was married in a civil ceremony and has two unbaptised children. Lorraine Ryan has described Elena's social position as a Republican widow as putative, publically rendering her as 'an assailable, sexualized object'. ${ }^{15}$ Salvador's discovery of Elena's true identity acts as the linchpin of the narrative: he feels betrayed by Elena's efforts to hide her Republican past, and so switches quickly from victim of catholic dogma to perpetrator of sexual violence.

10 Cuerda portrays this transition through an objective correlative which symbolises the character's traumatic containment: the wardrobe. In her analysis of 1950's American post-traumatic literature, Elizabeth Wheeler has noted a repeated transference of emotional traumatic containment onto landscape. As she explains, "past trauma lives in the psyche as an encapsulated island, quarantined away from the rest of memory'. ${ }^{16}$ This isolation of a traumatic event within an individual's memory has also been explored by Abraham and Torok, who termed this mode of inadvertent forgetting 'preservative repression'. They assert that 'the segment of an ever so painfully lived Reality - untellable and therefore inaccessible to the gradual, assimilative work of mourning - causes a genuinely covert shift in the entire psyche.' This, in turn, leads to the 'establishment of a sealed off psychic place, a crypt in the ego'. ${ }^{17}$ Wheeler has interpreted this term to explore how contained or concealed trauma has been transcribed onto geographical landscapes by post-war writers; an extreme mode of pathetic fallacy, or anthropomorphism, which is uniquely characteristic of post-war American short stories. However, it could be argued that this technique is also employed in Blind Sunflowers as an objective correlative, or a sartorial analogy. For Salvador, his wardrobe contains a potent symbol of the Civil War which represents the other side of his Janus-faced personality: his military uniform. There is a significant close-up shot of the uniform in Salvador's suitcase early on in the film, before he carefully places it inside his wardrobe when he is first settling into his boarding house. Much later on, after Elena's position as a Republican 
widow has been made apparent to Salvador, she finds him pacing the corridor outside their apartment wearing the colours of the Nationalist army. The delicate balance of social mores which has contained his sexual frustration finally breaks. The simpering, insipid priest suddenly erupts with a righteous violence and in a typically melodramatic narrative denouement, he attacks, insults and then tries to rape Elena. Salvador the soldier is a very different man to Salvador the deacon; donning his uniform performatively unleashes all the pent up anger and aggression of the battlefield. The wardrobe cannot contain his traumatic memories any longer, and the repercussions on his psyche are immediately evident.

11 This intertwining of military culpability and sexual shame creates a layering of guilt, a multiplication of both responsibility and suffering. Salvador himself feels guilty for his role during the conflict and guilty for his inability to resist the devil's temptation as manifested in Elena. He holds the Church responsible for his former shame, and Elena responsible for the latter. The shame of his attraction to the Republican widow also serves to obscure his guilt about his war crimes; it is no coincidence that Salvador only speaks of his military career at the start of the film, before he meets Elena. The script is peppered with military metaphors and euphemisms throughout, but only in the speech of the ecclesiasts; further testament to the way in which Salvador has been effectively brainwashed first by the dogma of Catholicism, and later by the propaganda of Francoism. This obfuscation of guilt by shame and vice versa creates what Thomas Elsaesser has termed a 'parapraxis argument', where two feelings substitute each other in a continual process of layering, but their fundamental irreconcilability results in a performative failure. ${ }^{18}$ In other words, by substituting guilt over the war for guilt over his sexual attraction to Elena and accepting responsibility for neither, Salvador is unable to escape the overwhelming sense of shame he feels. This is the performative failure, and it results in a double bind: Salvador's feelings of guilt provoke him to return to a state of violent aggression, which in turn results in the creation of further shame and culpability. This layering of weighty guilt blurs the lines between victim and perpetrator, and provokes an inevitable (if somewhat uncomfortable) economy of empathy between the audience and the perpetrator. The complicit role of the Church and the indirect responsibility of the wider community in this dynamic enables the film to present Salvador as a victim of circumstance. He is portrayed as a man who has been deeply traumatised by his role in the Civil War and denied the ability to satisfy some basic physical needs by his vocation. He is both perpetrator and victim, a site of conflict between religious piety and sexual desire, between the marginalisation of his political bigotry and an overwhelming desire for intimacy. The primacy of emotional interaction between audience and character created by the middlebrow allows this dialectical, nonessentialist view of perpetrator guilt to emerge.

\section{The affective political family in The Sleeping Voice}

12 Narratives centred upon families are frequently used in historical films to communicate the reality of living through times of political upheaval. The reliance of these narratives upon emotion and affect enables the articulation of experiences that do not adhere to the binaries of public versus private or individual versus political. The centrality of the familial context is also a recurrent characteristic of the middlebrow, concerned as it is with mixing the immediacy of the quotidian with the comparative detachment of high 
art. The character of Pepita in Benito Zambrano's The Sleeping Voice (La voz dormida, 2011) demonstrates how emotional motivation born of familial loyalty can compete with the incentive of ideological fervour. Set in the immediate post-war period, the film is an adaptation, another typically middlebrow characteristic, of the popular novel by Dulce Chacón. Pepita, played by María León, has moved to Madrid from Córdoba in order to support her imprisoned elder sister Hortensia (Inma Cuesta). Hortensia's husband Felipe (Daniel Hoguín) is still at liberty, fighting with a group of Communist guerrillas stationed in the mountains outside Madrid. The communication channels between female inmates and communist maquis have collapsed just prior to Pepita's arrival, and after an emotional reunion at the prison, Hortensia asks Pepita to carry a message to her husband. When she arrives at the meeting point in the sierra and encounters the handsome guerrilla fighter Paulino (Marc Clotet) for the first time, her comic Andalusian turns of phrase seem completely incongruous to the context. Pepita's attire in the woods - high heeled shoes, stockings, skirt and black dress coat - aptly demonstrates this contrast, as does her impeccably coifed hair and smooth skin, which becomes starkly opposed to that of the female prisoners as the film progresses. Pepita is coded as young, innocent, naive and provincial: she is quick to raise her voice at inopportune moments, asks intimate and potentially dangerous questions regarding the identity of the maquis and has a perpetually wide-eyed expression which gives her the appearance of being completely overwhelmed and confused in the political, urban environment in which she finds herself. Her initially reluctant involvement with the maquis soon develops into a much stronger association with their political struggle, encouraged by her love for Paulino and dedication to her imprisoned sister and unborn niece. This familial structure provides both the context and motivation for Pepita's character development, which demonstrates the effect of a violent, masculine, urban environment upon a naive, politically disinterested and provincially-minded young woman. This integration of the political and the personal allows this middlebrow film to create an emotionally affective platform from which to explore discourses surrounding the treatment of female prisoners and police brutality.

13 Although the political context of The Sleeping Voice is all-pervasive, family is the axis around which the film revolves. Pepita's motivation to continue fighting against the political repression and poverty which surrounds her is to support her sister and brotherin-law to fight for their Communist ideals. Hortensia is soon condemned to death and Pepita finds herself drawn into a relationship with Paulino. Both experiences are profoundly sobering for the young woman and prompt her to quickly mature, a journey which is manifested through the transformation of her previous naivety into a quiet, resistant determination. Throughout the film a tracking camera is used to follow either Pepita or Hortensia wherever they go. The frame rocks and bounces, imitating the movements of a silent, invisible actor sharing their point of view with the audience. This not only places the sisters and their relationship at the centre of the narrative, but also creates a sense of intimacy between the characters and the audience, so that the audience becomes another subject placed within the familial context. Reverse shots repeatedly show the sisters' points of view, inverting the technique traditionally used to position the male as dominant bearer of the look according to the Lacanian mirror stage, whereby a child recognises its reflection in a mirror and gains a sense of itself in a threedimensional space. Lacan's process also allows for the identification of other objects within this space, creating the founding moment of the Imaginary: the field of 
interrelations between subject and other people or objects. Laura Mulvey has used this concept to explore the representation of male figures in narrative cinema. If the camera movement is determined by the male hero, it reveals how the male image is positioned within a 'three-dimensional space corresponding to that of the mirror recognition;' he is 'free to command the stage, a stage of spatial illusion in which he articulates the look and creates the action'. ${ }^{19}$ Mulvey also identifies the use of deep focus in enhancing the depth and extent of a space in which the hero can move, and this is a technique also employed for a female subject in The Sleeping Voice. Aside from the tracking shot and shot reverseshot dyads depicting conversation, the camera is often positioned so that Pepita inhabits the middle-ground in a wide-angle frame. When she is the only figure in the shot, the entire concentration of the frame is focussed on the female subject, who is at once the centre of attention and yet completely isolated within the tableau. The central female subject can be read to signify the intimate and the familial, and she is frequently positioned alone in long-range shots of war-time Madrid that offer a visual correlative of the political and the public. These shots punctuate the film at regular intervals, intersecting the close-angle dyads and claustrophobic prison scenes that constitute the majority of the action. They provide a visual orientation of the private within the public, the individual within the political - blurring these rigid binaries of demarcation and articulating how a specifically private experience is concurrently public and political.

Zambrano's unwavering concentration of the camera on María León and Inma Cuesta effectively positions their relationship, and the importance of family over the political, as the central leitmotif of the film. Due to her sister's associations with the maquis resistance fighters, Pepita is suspected of being able to identify the infamous 'black jacket', her lover Paulino. She is arrested and taken to a damp, dark room depicted in hues of green and brown. When she refuses to cooperate with the police she is struck violently around the face and her shirt is ripped open. Live spark plugs are brandished in front of her face as she is questioned again. Resolute, Pepita refuses to answer, and one by one the spark plugs are clamped on to her nipples. This scene serves not only to emphasis her subjugated position on the social hierarchy, but also how the political violence of Francoism was frequently used as a tool to intimately abuse women's bodies. It is formally affective, in addition to being emotively profound, and here I wish to cite Eugenie Brinkema's polemical proposal for radical formalism within affect theory in the humanities. Arguing against the notion of affect as a matter of expression or sensation for the spectator, Brinkema posits that any readings of affect should be completely removed from any emotive or visceral response it may provoke and be analysed purely as form. ${ }^{20}$ The form of anxiety, according to Brinkema, is composed of movements that are never fully realised or completed, but rather formed of halting, stuttering, never-arriving movements. With recourse to Kierkegaard, Lacan and Freud, she interprets anxiety as a movement which embodies the fear of something which has not quite, yet, come into being, as the fear of a possibility which is still only a nothing, but a nothing that churns. 'The form of anxiety, then, is a form-in-process or a gesture of difficult movement, a choking movement, a movement that does not take place and that does not-enough arrive'. ${ }^{21}$ Another of Elsaesser's performative failures.

Anxiety is created in this scene through the movement of the camera, the colour pallette and the soundtrack. Pepita's dress has been ripped open and her breasts exposed to the cold air, the temperature conveyed by the saturation of damp blues and greens. Her exposed skin is the only warm colour in the shot framing, her chair is positioned in a 
weak beam of winter sunlight which highlights the pink in her skin, emphasising the vulnerability of her soft, fleshy body within a cold, hard, male milieu. She appears chromatically incongruent and discordant, but also isolated. She is the only woman in the room, tied to a chair, stripped naked in front of seven men and about to be electrocuted. The dirty yellow colour of the light-bulb positioned between Pepita and her torturer figures as a harbinger of the pain of contact between naked skin and electric current. It is situated both above and behind them, spatially positioned in the 'future' so as to create an anxiety of what is yet to come. The camera movement is abrupt, jumpy, awkwardly choked. The shaky hand-held frame positions the viewer inside this room, but renders them incapable of intervening, creating a sense of frustration. The camera flits from one angle to the next: we see Pepita face on, then from a high tilt angle, then as a reverse angle shot, then simply as an out-of-focus border of flesh around the frame. Aurally, anxiety is created through repetition; the policeman demands to know 'where, where, where' the Communists are hiding and Pepita repeatedly responds 'I don't know, I don't know.' These questions escalate into shouts and there are sudden, violent movements as Pepita is slapped and her brother-in-law is kicked into submission. When the spark plugs are applied, Pepita screams and the sparks crackle loudly. This compilation of frenetic action, chromatic dissonance and distorting sounds creates an impression of juddering movement on the screen - every aspect of the composition is hectic, clashing, violent, yet impotent, frustrated, choked. The form of anxiety is thus combined with the symbolic exposure of female intimacy within a violent political context. Individuality is invaded by the political, blurring the binaries of private and public.

This torture scene makes for uncomfortable viewing, but it is brief and singular, and contained within a narrative arc of redemptive familial and romantic love. By using an emotional register centred on the experiences of an individual and her family, The Sleeping Voice is able to explore some uncomfortable truths around the treatment of Republican and Communist women under Franco within a familiar and comprehensible structure. The same generic methodology enables Blind Sunflowers to articulate a new discourse around perpetrator trauma and responsibility. The middlebrow therefore continues to respond to social issues off-screen in providing a platform on which controversial topics can be articulated and visually rendered in an accessible manner. Hake proposes that 'as the most important mass medium of the twentieth century, film not only continues to provide powerful stories and images but also uses its own historicity to convey a sense of cultural tradition and historical continuity', ${ }^{22}$ and this is particularly pertinent to the ever-expanding corpus of middlebrow Civil War films. They may at times be blighted by dismissive critical reviews, but they continue to provide an essential site of engagement between cinema, history and social discourse.

\section{BIBLIOGRAPHY}

Abraham, Nicolas \& Maria Torok, The Shell and the Kernel, vol. 1, trans. by Nicholas T. Rand (Chicago \& London: The University of Chicago Press). 
Bourdieu, Pierre, Distinction: A Social Critique of the Judgement of Taste, trans. by Richard Nice (London: Routledge, 1999).

Brinkema, Eugenie, The Forms of The Affects (Durham and London: Duke University Press, 2014).

Elsaesser, Thomas, German Cinema. Terror and Trauma. Cultural Memory since 1945 (New York \& Oxon: Routledge, 2014).

Faulkner, Sally, A History of Spanish Film. Cinema and Society 1910-2010 (New York, London : Bloomsbury, 2013).

Hake, Sabine, Screen Nazis. Cinema, History, and Democracy (Madison, Wisconsin : University of Wisconsin Press, 2012).

Lassner, Phyllis, 'Testing the Limits of the Middlebrow : The Holocaust for the Masses' in Modernist Cultures, vol. 6, No.1 (2011), pp. 178-195.

Mulvey, Laura, Visual and Other Pleasures (London: Macmillan, 1989), p. 20.

Riambau, Esteve, 'El periodo <<socialista>> (1982-1995)' in Gubern et al. eds., Historia del cine español, 7th edn. (Madrid : Ediciones Cátedra, 2010).

Ribeiro de Menezes, Alison, Embodying Memory in Contemporary Spain (New York : Palgrave Macmillan, 2014).

Ryan, Lorraine, Memory and Spatiality in Post-Millennial Spanish Narrative (Farnham: Ashgate Publishing Limited, 2014).

Vilarós, Teresa, El mono del descanto : una crítica cultural de la transición española (1973-1993)

(Madrid : Siglo Veintiuno, 1998).

Wheeler, Elizabeth A., Uncontained : Urban Fiction in Postwar America (New Brunswick, New Jersey \& London : Rutgers University Press, 2001).

\section{NOTES}

1. Sabine Hake, Screen Nazis. Cinema, History, and Democracy (Madison, Wisconsin: University of Wisconsin Press, 2012), 4.

2. Sally Faulkner, A History of Spanish Film. Cinema and Society 1910-2010 (New York, London: Bloomsbury, 2013), 238.

3. Faulkner, 4.

4. Teresa Vilarós, El mono del descanto: una crítica cultural de la transición española (1973-1993) (Madrid: Siglo Veintiuno, 1998), 239.

5. Esteve Riambau, 'El periodo <<socialista>> (1982-1995)' in Gubern et al. eds., Historia del cine español, 7th edn. (Madrid: Ediciones Cátedra, 2010), 402.

6. Pierre Bourdieu, Distinction: A Social Critique of the Judgement of Taste, trans. by Richard Nice (London: Routledge, 1999), 324.

7. Faulkner, 5.

8. Phyllis Lassner 'Testing the Limits of the Middlebrow: The Holocaust for the Masses' in

Modernist Cultures, Vol. 6, No.1 (2011), 180.

9. Lassner, 181.

10. Lassner, 188.

11. After the death of Franco in 1975, a 'pact of silence' was imposed by the transitional government in order to facilitate a smooth transition from dictatorship to democracy and avoid 
any reprisals against members of the new government who were inextricably linked to the Francoist state. This resulted in the stories of those who had suffered during the war and the dictatorship being silenced and any acts of public mourning for the dead were denied.

12. Hake, 15.

13. Alison Ribeiro de Menezes, Embodying Memory in Contemporary Spain (New York: Palgrave Macmillan, 2014), 97.

14. Translations are my own.

15. Lorraine Ryan, Memory and Spatiality in Post-Millennial Spanish Narrative (Farnham: Ashgate Publishing Limited, 2014), 105.

16. Elizabeth A. Wheeler, Uncontained: Urban Fiction in Postwar America (New Brunswick, New Jersey \& London: Rutgers University Press, 2001), 56.

17. Nicolas Abraham \& Maria Torok, The Shell and the Kernel, Vol. 1, trans. by Nicholas T. Rand (Chicago \& London: The University of Chicago Press), 14.

18. Thomas Elsaesser, German Cinema. Terror and Trauma. Cultural Memory since 1945 (New York \& Oxon: Routledge, 2014), 297.

19. Laura Mulvey, Visual and Other Pleasures (London: Macmillan, 1989), 20.

20. Eugenie Brinkema, The Forms of The Affects (Durham and London: Duke University Press, 2014), 36.

21. Brinkema, 201.

22. Hake, 7.

\section{ABSTRACTS}

Films set during or immediately after the Spanish Civil War have a long tradition in Spain, one which spans the entire spectrum of filmic genres, from propaganda to musicals to art-house. This genre has not abated since the turn of the century, it has become increasingly ubiquitous and since the late 1990s, undeniably 'middlebrow'. Yet this prolific genre, on the whole, is largely snubbed by films critics and academic researchers alike. The old adage of 'oh not another civil war film' remains widely recurrent in the press, but the fact that many, if not all, of these productions deal with narrative tropes that are of profound social relevance warrants further investigation. By analysing the primacy of emotion and affect in two films, Blind Sunflowers (Los Girasoles Ciegos, 2009) and The Sleeping Voice (La voz dormida, 2011), this article argues that civil war films constitute a sub-genre of the Spanish middlebrow which is exceptionally, yet controversially, well-suited to the exploration of socially and culturally traumatic themes.

\section{INDEX}

Mots-clés: Spanish Civil War Films, affect, perpetrator trauma, The Sleeping Voice, Blind Sunflowers. 


\section{AUTHOR}

\section{LAURA J. LEE KEMP}

University of Cambridge

Laura Lee Kemp completed her PhD in contemporary Spanish Civil War cinema at the University of Cambridge in 2016, after gaining a Masters from the University of Bristol. She has published on the televisual mini-series The Time Between The Scenes and on the notion of 'heritage' cinema in Spain. 